\title{
Evaluation of the Antidote Activity of Nimbu swarasa (Citrus limon Linn.) on Jayapala Seed (Croton tiglium Linn.) Induced Toxicity in Wistar Albino Rats
}

\author{
Mouneshwari', Ravi Mundugaru², Shobha Bhat Kodavoor ${ }^{3,4, *}$ \\ ${ }^{1}$ Department of Agada Tantra, Dhanvantari Ayurveda Medical College, Hospital and Research Centre, Siddapura, Karnataka, INDIA. \\ ${ }^{2}$ Department of Pharmacology, DM WIMS, Wayanad, Kerala, INDIA. \\ ${ }^{3}$ Department of Agada Tantra, Faculty of Ayurveda, Institute of Medical Sciences, Banaras Hindu University, Varanasi, \\ Uttar Pradesh, INDIA. \\ ${ }^{4}$ Department of Agada Tantra, SDM College of Ayurveda, Kuthpady, Udupi, Karnataka, INDIA.
}

\begin{abstract}
Background: Seeds of Jayapala (Croton tiglium Linn.) is a toxic compound which is commonly used in several Ayurvedic formulations following proper detoxification methods as mentioned in the Ayurvedic classics. Adarsha nigantu, one of the treatises of Ayurveda explains Nimbu swarasa (Lemon juice) as an antidote for Jayapala. The present study was aimed to determine the antidote activity of Nimbu swarasa (Citrus limon linn.) on Jayapala (Croton tiglium Linn.) seed induced toxicity on Wistar albino rats. Materials and Methods: A sub acute toxicity study was conducted on Wistar rats following the repeated dose 28 day oral toxicity study in rodents, 407 OECD guidelines which included administration of Jayapala seeds alone in one group and Jayapal seeds along with Nimbu swarasa in different doses in the other groups. Different haematological and biochemical parameters along with histopathology of important organs were carried out to access the antidote effect of Nimbu swarasa. Observation and Results: The repeated administration of Jayapala seed powder caused significant elevation in the serum liver enzymes like SGOT and SGPT ( $\left.{ }^{*} P<0.5\right)$ and marked rise in the serum creatinine level. The co-administration of antidote Nimbu swarasa significantly attenuated Jayapala seed induced increase in the liver enzymes and reduced serum creatinine level. Histopathological examination of colon and jejunum revealed moderate epithelial cell erosions in Jayapala seeds administered group, whereas Nimbu swarasa caused mild to moderate protection in a dose dependant manner. Sections of spleen showed remarkable increase in the proportion of white pulp in toxicant group, whereas the Nimbu swarasa at higher dose level showed marked decrease in the white pulp proportion. The hepatic sections of toxicant group displayed mild cell infiltration and fatty changes in the hepatocyte with mild diffused necrosis whereas the sections of co-administration of antidotes showed normal cytoarchitecture. Conclusion: All the above findings are suggestive of Nimbu swarasa being an effective antidote against Jayapala induced toxicity.
\end{abstract}

Key words: Antidote, Jayapala seeds, Nimbu swarasa, Haematological parameters, Histopathological examination, Toxicity.

\section{INTRODUCTION}

The text books of toxicology in Ayurveda describe Jayapala (Croton tiglium Linn.) as one among the Upavisha (A group of toxic plants). ${ }^{1}$ Croton tiglium Linn. belongs to the family Euphorbiaceae, is a native to tropical Asia, adaptable to any climate and found in lands ranging from subtropical moist to tropical dry and throughout the wet forest. It grows all over India and is also cultivated as a house plant. ${ }^{2}$ Ayurveda advocates its use in inducing Virechana (Purgation), in Jalodara (ascitis), Navajwara (type of fever), Krimi (worm infestation), Kushta (Skin disorders), Vrishchika visha (Scorpion poisoning).
Submission Date: 24-07-2020; Revision Date: 24-03-2021; Accepted Date: 09-08-2021

DOI: 10.5530/ijper.55.3s.184 Correspondence: Dr. Shobha Bhat $K$, Professor and Head, Department of Agad Tantra, Faculty of Ayurveda, Institute of Medical Sciences, Banaras Hindu University, Varanasi-221005, Uttar Pradesh, INDIA. Phone: +91 9482487321, Email - drbhatshobha@ gmail.com

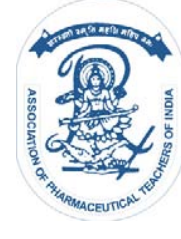

www.ijper.org 
It is a common ingredient in clinically used formulations like Icchabhedirasa, Jalodarari rasa, Jwarari rasa, Anjana bhairava rasa (Names of Ayurvedic formulations) etc. ${ }^{3}$ It is extensively used for the treatment of constipation, dyspepsia, gastrointestinal disorders, intestinal inflammation, rheumatism, peptic ulcer, visceral pain and headache. ${ }^{4-6}$ The seeds and seed oil are known to be toxic. ${ }^{7}$ Seeds are albuminous, ovate, oblong, slightly quadrangular, convex on dorsal and somewhat flattened on ventral surface, about $12 \mathrm{~mm}$ in length and resemble castor seed in shape. ${ }^{8}$ Crotonic acid, crotonoleic acid and several other fatty acids are the toxic chemical in Croton tiglium which restricts its potential therapeutic use. ${ }^{9}$ The seeds contain this toxalbumin which inhibit protein synthesis by disabling the ribosomes, causes hemolysis and cell destruction. ${ }^{10-12}$

The text books of Ayurveda advocate a special procedure called Shodhana (detoxification) which is a unique process of detoxification employed to purify or detoxify such toxic drugs used in Aynrvedic medicine with a view to reduce their toxic contents or effects as well as to enhance their therapeutic properties. Different procedures of Shodhana have been explained for Jayapala and it is used as a medicine only after the method of Shodhana is followed. But unfortunately, due to various reasons, such medicines may cause harmful effects in patients. Therefore it is mandatory for a physician to have knowledge of a proper antidote to such toxic drugs which can be used effectively when required. References for the specific antidotes for the Upavisha may be seen in different Nighantu. (A set of text books of Ayurveda) Dugdha (milk), Dadhi (curd) and Nimbu swarasa (Lemon juice) are explained as the antidotes for Jayapala in the Nighantu Adarsha (One of the Ayurvedic text books). ${ }^{13} \mathrm{~A}$ pilot study was planned to access the acute toxicity of Jayapala and the antidotal effect of Nimbu swarasa (lemon juice) on Jayapala induced toxicity just based on certain parameters related to the Gastro-intestinal tract which showed positive response of the antidotal activity. ${ }^{14}$ Hence a detailed experimental study was planned with an intension to evaluate the antidote activity of Nimbu swarasa on Jayapala induced toxicity on Wistar rats.

\section{MATERIALS AND METHODS}

\section{Collection of test drugs}

The test drugs used in the study were Jayapala (Croton tiglium) seeds and lemon juice. Jayapala (Croton tiglium) seeds were purchased from local Ayurvedic drug market of Udupi, Karnataka. Lemon was purchased from the local market in Udupi. Both the drugs used were identified by the Department of Dravyaguna, SDM College of
Ayurveda, Udupi, Karnataka. The outer shell of Croton tiglium seeds was removed, seeds shade dried at ambient temperature, crushed to obtain fine powder and stored in airtight container. Ripe, yellow lemon was used in the study. Nimbu swarasa (Lemon juice) was prepared freshly by cutting it, squeezing with hand and filtering, before administration.

\section{Rationale behind fixation of the dose of the drugs}

An acute oral toxicity test was conducted prior to this study which concluded the $\mathrm{LD}_{50}$ of jayapala as $2000 \mathrm{mg} / \mathrm{kg}$, hence the animal dose for this study was concluded as $1 / 5^{\text {th }}$ of $\mathrm{LD}_{50}$ which is $400 \mathrm{mg} / \mathrm{kg}$ body weight. Fresh extract of a herb in liquid form, extracted from any of its part like stem, fruit, flower, roots etc is termed as Swarasa kalpana (Fresh juice extracts) in Ayurveda. Since lemon juice was used as the antidote, the dose of swarasa kalpana (fresh juice extract) as mentioned in the Ayurvedic classics was selected as the dose of the antidote. $(1 / 2 \mathrm{Pala}=24 \mathrm{ml})$. This dose was converted to the rat dose and the study planned with TED and 2xTED dose.

\section{Experimental animals}

Wistar albino rats of either sex weighing between $200 \pm 50 \mathrm{~g}$ body weights and an average of 5 months of age were used for the experimental study. The animals were obtained from animal house attached to the pharmacology laboratory, S.D.M Centre for Research in Ayurveda and Allied Sciences, Udupi, Karnataka. IAEC clearance was obtained for the study and experiments were conducted as per the guidelines of Institutional Animal Ethical Committee, according to Government of India accepted principles for laboratory animals' use and care. (IAEC no. SDMCAU/IAEC/2013-14-11). The animals received humane care, in compliance with the host institutional animal ethics guidelines. They were exposed to natural day and night cycles with ideal laboratory condition in terms of ambient temperature, humidity. They were fed with rat pellets supplied by Sai Durga feeds, Bengaluru and tap water ad libitum.

\section{Experimental protocol}

An acute toxicity study of Jayapala seeds was performed as a part of the pilot study, based on OECD 423 test guidelines which reported the $\mathrm{LD}_{50}>2000 \mathrm{mg} / \mathrm{kg}$ body weight and hence $400 \mathrm{mg} / \mathrm{kg}$ body weight was chosen as dose for the current study. ${ }^{14}$ The rats which were found appropriate to the study based on their weight and age were marked from 1 to 24 and using lottery method were randomly divided into four groups, with 6 rats in each group. No inclusion or exclusion criteria were fixed. Group I rats were administered with $0.5 \%$ gum 
acacia and considered as vehicle control. Group II rats were administered with Jayapala seed powder $(400 \mathrm{mg} / \mathrm{kg})$ made suspension in $0.5 \%$ gum acacia. Group III and IV administered with Jayapala seed powder $(400 \mathrm{mg} / \mathrm{kg})$ made suspension in $0.5 \%$ gum acacia along with Nimbu swarasa 5 and $10 \mathrm{ml} / \mathrm{kg}$ dose respectively. Animals were kept on acclimatization for 7 days. Group specific drugs were administered for 28 consecutive days using oral catheter fit to a syringe. On $28^{\text {th }}$ day all animals were kept for overnight fasting. Next day blood was collected by supra-orbital puncture with the help of micro capillary tubes under mild ether anaesthesia for estimation of serum biochemical and haematological parameters followed by sacrifice with over dose of ether anaesthesia. The abdomen was cut opened through midline incision to record the autopsy changes followed by dissecting out the important organs and extraneous tissues was removed and weighed. The tissue was transferred to bottles containing 10\% formalin for the purpose of histopathological study.

\section{Outcome measures: Estimation of haematological and biochemical parameters}

Blood samples were taken from the orbital plexuses, using capillary tubes, under anaesthesia at the end of the period or collected just prior to or as part of the procedure of humane sacrifice. The haematological parameters like haematocrit, hemoglobin concentration, erythrocyte count, total and differential leucocyte count, platelet count etc were measured using 'Aggape mindra' auto cell counter. Determinations of biochemical parameters in plasma or serum were glucose, urea, creatinine, total protein, SGOT, SGPT, and ALP. In all these procedures requisite quantity of serum was fed to the 'Erba 360' fully automatic biochemical analyser to obtain the results. The person conducting these parameters was blinded and had no knowledge of the treatment allocation to both the groups of the study.

\section{Histopathological study}

Brain, heart, liver, spleen, lungs, kidney, stomach, jejunum, testis, uterus were the organs subjected to histopathological study. After noting the weight of the organ they were transferred to $10 \%$ formaldehyde solution for fixation and sent to a commercial laboratory for preparation of slides. The slides with sections obtained were scanned in Trinocular Carl Zeiss's microscope (Germany) under different magnifications. Changes, if any in the cytoarchitecture were noted down.

\section{Statistical analysis}

The results were expressed as mean $\pm S D$ where each value represents a minimum of 6 rats $\left(n^{1 / 46}\right)$. The data for relative organ weights, haematology and serum biochemistry were tested using unpaired student $t$ test in which the results were compared with that of control rats. The results were considered statistically significant at $p \leq 0.05$ level. GraphPad Prism (Cversion 3.5 for Windows (Graph Pad Software, USA) was used for all statistical analysis.

\section{RESULTS}

Effect of Nimbu swarasa in Jayapala seeds induced haematological changes.

The haematological parameters such as haemoglobin, WBC, RBC, PCV, MCV, MCH, MCHC, RDWSD, RDWCV, RDWSD and platelet were estimated to analyse the haematological toxicity of caused by Jayapala seeds in Wistar albino rats. Among these parameters we could observe significant increase in the RDWSD in Jayapala seed administered along with double the therapeutic dose of Nimbu swarasa in Jayapala alone group. However rest of the parameters were comparable with that of normal control group (Table 1).

\section{Effect of Nimbu swarasa in Jayapala seeds induced hepatic toxicity}

Repeated administration of Jayapala seed extract caused significant increase in the liver enzymes especially SGOT and SGPT with marked increase in the ALP as compared to control group (" $p<0.05)$. Co-administration of Nimbu swarasa in both dose levels significantly attenuated the Jayapala induced liver toxicity by reducing SGOT level as compared to Jayapala alone group $(" p<0.05)$, whereas marked reduction in the SGPT and ALP level as compared to Jayapala alone group (Table 2).

\section{Effect of Nimbu swarasa in Jayapala seeds induced renal toxicity}

Repeated administration of Jayapala seed extract caused marginal decrease in the urea and slightly increase in the serum creatinine level as compared to control group, however it was not statistically significant in comparison to normal control. Co-administration of Nimbu swarasa at therapeutic dose significantly reduced serum creatinine level as compared to Jayapala alone group $(" p<0.05)$ (Table 3).

\section{Effect of Nimbu swarasa in Jayapala seeds induced electrolyte changes}

Jayapala administered group has shown significant decrease in the sodium concentration in comparison to control group $(" p<0.05)$, whereas the Nimbu swarasa co-administered group has shown non-significant elevation in the serum sodium level and comparable with 


\begin{tabular}{|c|c|c|c|c|}
\hline $\begin{array}{l}\text { Haematological } \\
\text { parameters }\end{array}$ & Control & $\begin{array}{c}\text { Jayapala seed } \\
\text { (400mg/kg) }\end{array}$ & $\begin{array}{l}\text { Jayapala seed }(400 \mathrm{mg} / \mathrm{kg}) \\
+ \text { Nimbus warasa }(5 \mathrm{ml} / \mathrm{kg})\end{array}$ & $\begin{array}{c}\text { Jayapala seed } \\
(400 \mathrm{mg} / \mathrm{kg})+\text { Nimbus } \\
\text { warasa } \\
(10 \mathrm{ml} / \mathrm{kg})\end{array}$ \\
\hline $\begin{array}{l}\text { Haemoglobin } \\
(\mathrm{g} / \mathrm{dL})\end{array}$ & $14.88 \pm 0.21$ & $10.53 \pm 2.87$ & $14.53 \pm 0.81$ & $15.06 \pm 0.33$ \\
\hline $\begin{array}{c}\text { WBC } \\
\text { (cells/cumm) count }\end{array}$ & $12333.3 \pm 1709.1$ & $11450 \pm 1390.1$ & $8957.14 \pm 1673.3$ & $8320 \pm 958.85$ \\
\hline $\begin{array}{c}\text { RBC } \\
\text { (Millions/cumm) }\end{array}$ & $7.70 \pm 0.17$ & $7.70 \pm 0.18$ & $7.49 \pm 0.37$ & 7. $61 \pm 0.18$ \\
\hline $\begin{array}{l}\text { PCV } \\
(\%)\end{array}$ & $42.05 \pm 0.84$ & $42.11 \pm 1.13$ & $40.95 \pm 1.80$ & $43.34 \pm 1.22$ \\
\hline $\begin{array}{l}\mathrm{MCV} \\
(\mathrm{fl})\end{array}$ & $54.66 \pm 0.76$ & $54.71 \pm 0.76$ & $55.22 \pm 0.67$ & $57 \pm 0.75$ \\
\hline $\begin{array}{c}\mathrm{MCH} \\
\text { (picogram) }\end{array}$ & $19.28 \pm 0.22$ & $19.23 \pm 0.34$ & $19.6 \pm 0.24$ & $19.96 \pm 0.21$ \\
\hline $\begin{array}{c}\mathrm{MCHC} \\
(\%)\end{array}$ & $35.36 \pm 0.30$ & $35.76 \pm 0.22$ & $35.62 \pm 0.20$ & $35.12 \pm 0.38$ \\
\hline $\begin{array}{l}\text { RDWCV } \\
(\%)\end{array}$ & $13.68 \pm 0.24$ & $13.7 \pm 0.22$ & $13.95 \pm 0.23$ & $14.02 \pm 0.37$ \\
\hline $\begin{array}{l}\text { RDWSD } \\
\text { (FL) }\end{array}$ & $27.08 \pm 0.68$ & $26.11 \pm 0.36$ & $27.2 \pm 0.41$ & $28.5 \pm 0.84 @$ \\
\hline $\begin{array}{l}\text { Platelet count } \\
\text { (Lakhs/cumm) }\end{array}$ & $6.77 \pm 0.81$ & $6.50 \pm 0.53$ & $7.98 \pm 0.46$ & $7.11 \pm 0.44$ \\
\hline
\end{tabular}

Data expressed in $\mathrm{MEAN} \pm \mathrm{SEM}, * P<0.05$, \#-in comparison with control group, @- In comparison with Jayapala seed group.

WBC-White blood cells, RBC-Red blood cells, PCV-packed cell volume, MCV-Mean cell volume, MCH-Mean cell haemoglobin, MCHC-Mean cell haemoglobin concentration, RDWCV-Red cell distribution width coefficient variation, RDWSD- Red cell distribution width standard deviation

\begin{tabular}{|c|c|c|c|}
\hline \multicolumn{2}{|c|}{ Table 2: Effect of Nimbu swarasa in Jayapala seed induced hepatic toxicity. } \\
\hline Group & $\begin{array}{c}\text { SGOT } \\
\text { (IU/L) }\end{array}$ & $\begin{array}{c}\text { SGPT } \\
\text { (IU/L) }\end{array}$ & $\begin{array}{c}\text { Alkaline } \\
\text { phosphatise } \\
\text { (IU/L) }\end{array}$ \\
\hline Control & $122.7 \pm 2.19$ & $69.4 \pm 5.02$ & $459.83 \pm 69.21$ \\
\hline Jayapala seed (400mg/kg) & $156.06 \pm 14.06^{\#}$ & $134.13 \pm 20.44^{\#}$ & $782.66 \pm 97.04$ \\
\hline Jayapala seed (400mg/kg) +Nimbu swarasa $(5 \mathrm{ml} / \mathrm{kg})$ & $119.22 \pm 11.43^{@}$ & $91.17 \pm 4.73$ & $573.7 \pm 97.04$ \\
\hline Jayapala seed $(400 \mathrm{mg} / \mathrm{kg})+$ Nimbu swarasa $(10 \mathrm{ml} / \mathrm{kg})$ & $124.56 \pm 8.60^{@}$ & $97.1 \pm 19.22$ & $795 \pm 166.6$ \\
\hline
\end{tabular}

Data expressed in MEAN $\pm \mathrm{SEM}, * P<0.05, * * P<0.01$, \#-in comparison with control group, @- In comparison with Jayapala seed group.

SGOT-Serum glutamate oxaloacetate transaminase

SGPT - Serum glutamate pyrovet transaminase

Table 3: Effect of Nimbu swarasa in Jayapala seed induced renal toxicity.

\begin{tabular}{|c|c|c|}
\hline Group & $\begin{array}{c}\text { Urea } \\
\text { (mg/dl) }\end{array}$ & $\begin{array}{c}\text { Creatinine } \\
\text { (mg/dl) }\end{array}$ \\
\hline Control & $43.1 \pm 4.94$ & $0.67 \pm 0.03$ \\
\hline Jayapala seed $(400 \mathrm{mg} / \mathrm{kg})$ & $34.06 \pm 3.87$ & $0.70 \pm 0.02$ \\
\hline $\begin{array}{c}\text { Jayapala seed powder }(400 \mathrm{mg} / \\
\mathrm{kg})+ \text { Nimbuswarasa }(5 \mathrm{ml} / \mathrm{kg})\end{array}$ & $32.65 \pm 1.58$ & $0.56 \pm 0.0{ }^{@}$ \\
\hline $\begin{array}{c}\text { Jayapala seed }(400 \mathrm{mg} / \mathrm{kg})+ \\
\text { Nimbuswarasa }(10 \mathrm{ml} / \mathrm{kg})\end{array}$ & $38.64 \pm 5.26$ & $0.68 \pm 0.05$ \\
\hline
\end{tabular}

Data expressed in MEAN $\pm \mathrm{SEM}, * P<0.05, * * P<0.01$, \#-in comparison with control group, @- In comparison with Jayapala seed group. that of normal control group. Nimbu swarasa at double the therapeutic dose showed significant elevation in the serum potassium level as compared to Jayapala alone group $(* * * 0.01)$. There were no changes in the serum chloride level in Jayapala and Nimbu swarasa administered groups (Table 4).

\section{Ponderal changes}

Repeated administration of Jayapala seed powder lead to marginal increase in stomach and colon weight in comparison to normal control. However, in both the 


\begin{tabular}{|c|c|c|c|}
\hline Group & $\begin{array}{c}\mathrm{Na}^{+} \\
(\mathrm{mEq} / \mathrm{L})\end{array}$ & $\begin{array}{c}\mathrm{K}^{+} \\
(\mathrm{m} \text { Eq/L) }\end{array}$ & $\begin{array}{c}\mathrm{Cl}^{-} \\
(\mathrm{mEq} / \mathrm{L})\end{array}$ \\
\hline Control & $142.33 \pm 0.42$ & $4.18 \pm 0.24$ & $89.37 \pm 12.65$ \\
\hline Jayapala seed (400mg/kg) & $139.5 \pm 0.42^{\# \#}$ & $4.43 \pm 0.20$ & $102 \pm 3.15$ \\
\hline Jayapala seed powder(400mg/kg)+Nimbu swarasa $(5 \mathrm{ml} / \mathrm{kg})$ & $140.28 \pm 0.42$ & $4.95 \pm 0.17$ & $92.71 \pm 1.26$ \\
\hline Jayapala seed $(400 \mathrm{mg} / \mathrm{kg})+$ Nimbu swarasa $(10 \mathrm{ml} / \mathrm{kg})$ & $139.8 \pm 0.66$ & $7.96 \pm 0.24 @ @$ & $84.4 \pm 1.03$ \\
\hline
\end{tabular}

Data expressed in $\mathrm{MEAN} \pm \mathrm{SEM}, * * P<0.01$, \#-in comparison with control group, @- In comparison with Jayapala seed group. $\mathrm{Na}^{+}$- Serum sodium level, $\mathrm{K}^{+}$- Serum potassium level, $\mathrm{Cl}$-Serum chloride level

\begin{tabular}{|c|c|c|c|c|}
\hline Organs & Control & $\begin{array}{l}\text { Jayapala seed } \\
\text { (400mg/kg) }\end{array}$ & $\begin{array}{l}\text { Jayapala seed }(\mathbf{4 0 0} \mathrm{mg} / \mathbf{k g}) \\
+ \text { Nimbu swarasa }(5 \mathrm{ml} / \mathbf{k g})\end{array}$ & $\begin{array}{c}\text { Jayapala seed }(400 \mathrm{mg} / \mathbf{k g})+ \\
\text { Nimbuswarasa }(10 \mathrm{ml} / \mathbf{k g})\end{array}$ \\
\hline Stomach (g) & $1.20 \pm 0.12$ & $1.34 \pm 0.04$ & $1.31 \pm 0.07$ & $1.36 \pm 1.36$ \\
\hline Colon (g) & $0.50 \pm 0.06$ & $0.65 \pm 0.04$ & $0.57 \pm 0.03$ & $0.75 \pm 0.08$ \\
\hline Liver (g) & $7.08 \pm 0.87$ & $6.68 \pm 0.31$ & $6.14 \pm 0.21$ & $7.21 \pm 0.58$ \\
\hline Kidney (g) & $1.44 \pm 0.11$ & $1.25 \pm 0.07$ & $1.37 \pm 0.12$ & $1.40 \pm 0.11$ \\
\hline Lungs (g) & $1.44 \pm 0.11$ & $1.26 \pm 0.02$ & $1.14 \pm 0.05$ & $1.66 \pm 0.07^{\star *}$ \\
\hline Spleen (g) & $0.81 \pm 0.13$ & $0.62 \pm 0.07$ & $0.43 \pm 0.02$ & $0.50 \pm 0.02$ \\
\hline Heart (g) & $0.67 \pm 0.04$ & $0.72 \pm 0.03$ & $0.79 \pm 0.05$ & $0.75 \pm 0.06$ \\
\hline Duodenum (g) & $0.49 \pm 0.03$ & $0.48 \pm 0.04$ & $0.35 \pm 0.04$ & $0.39 \pm 0.06$ \\
\hline Testis (g) & $2.57 \pm 0.14$ & $2.32 \pm 0.42$ & $2.63 \pm 0.19$ & $2.29 \pm 0.19$ \\
\hline Uterus(g) & $0.75 \pm 0.01$ & $0.66 \pm 0.05$ & $0.87 \pm 0.12$ & $0.46 \pm 0.02$ \\
\hline
\end{tabular}

Data expressed in $\mathrm{MEAN} \pm \mathrm{SEM}, * * P<0.01$

antidote groups, no significant effect could be observed in comparison to Jayapala alone given group. Administration of Jayapala lead to a marginal and statistically non- significant decrease in liver, kidney, lungs, spleen, heart, duodenum, testis and uterine weight in comparison to normal control. In the antidote groups of both doses, a moderate increase was observed in comparison to Jayapala alone given group. However, the observed change was found to be statistically non-significant (Table 5).

\section{Histopathological Examination}

The histopathological examination of stomach, colon, jejunum, spleen, liver, heart, lungs, kidney, uterus and testis were carried out in the present study. In organs like stomach, heart, lungs, kidney, uterus and testis, there were no significant pathological changes and we could see normal cytoarchitecture. Representative sections of microscopic examinations of sections of colon from control and test group are depicted in Figure 1. Mild epithelial erosion was observed in sections from group administered with Jayapala seed powder alone. Groups co-administered with Nimbu swarasa in both the doses exhibited shortening of the epithelial layer and almost normal cytoarchitecture. Examination of jejunum sections from Jayapala seed induced group showed mild to moderate epithelial disruption. In Jayapala seed + Nimbu swarasa TED group, normal cytoarchitecture was observed in sections from two rats, epithelial disruption was observed in one rat and in another rat cell depletion was observed in epithelial layer. In Jayapala seed + Nimbu swarasa in double the TED group, sections from two rats were found to be normal; in sections from one rat necrosis of epithelial layer was observed and in sections form another rat- normal but slightly shortened epithelial layer was observed. Photographs of representative sections can be found in Figure 2. Microscopic examination of sections of spleen from 3 rats in Jayapala seed group showed remarkable increase in the proportion of white pulp while in one rat moderate increase in the proportion of white pulp was observed. Spleen sections from two rats in Jayapala seed + Nimbu swarasa TED exhibited marked increase in white pulp proportion while the increase was found to be mild in one rat and moderate in another rat. Spleen sections from all the rats examined in Jayapala seed + Nimbu swarasa $2 \times$ TED exhibited moderate increase in the proportion of white pulp. Photomicrographs of representative sections can be found in Figure 3. Microscopic examination of liver 


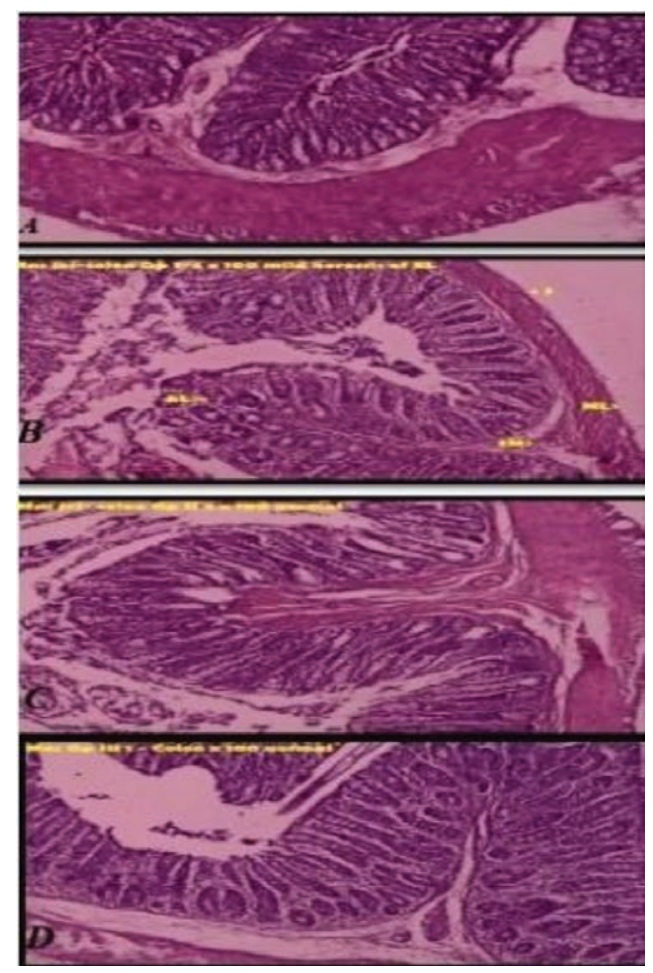

Figure 1: Photomicrograph of representative sections of Colon. A-Normal control, B-Jayapala Seeds, C- Jayapala Seeds + Nimbu swarasa (TED), D- Jayapala Seeds + Nimbu swarasa (TEDX2). Sm- Sub mucosal layer, Nc- Necrosis, MI- Muscular layer. El- Epithelial layer.

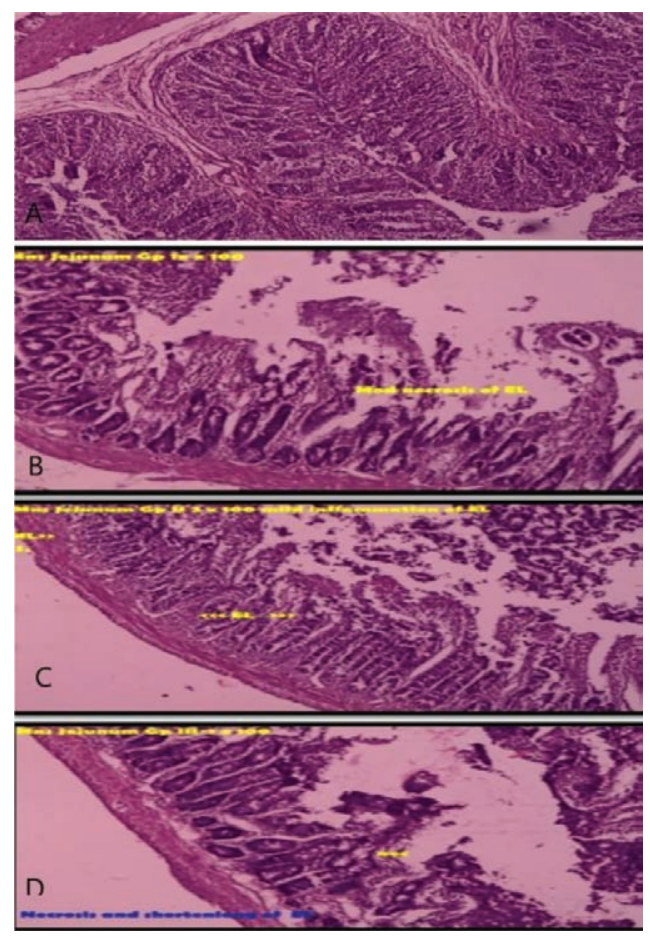

Figure 2: Photomicrograph of representative sections of Jeiunum. A-Normal control, B-Jayapala Seeds, C- Jayapala Seeds + Nimbu swarasa (TED), D- Jayapala Seeds + Nimbu swarasa (TEDX2). El- Epithelial layer, Nec- Necrosis cells, Sm- Sub mucosal layer, MI- Muscular layer.
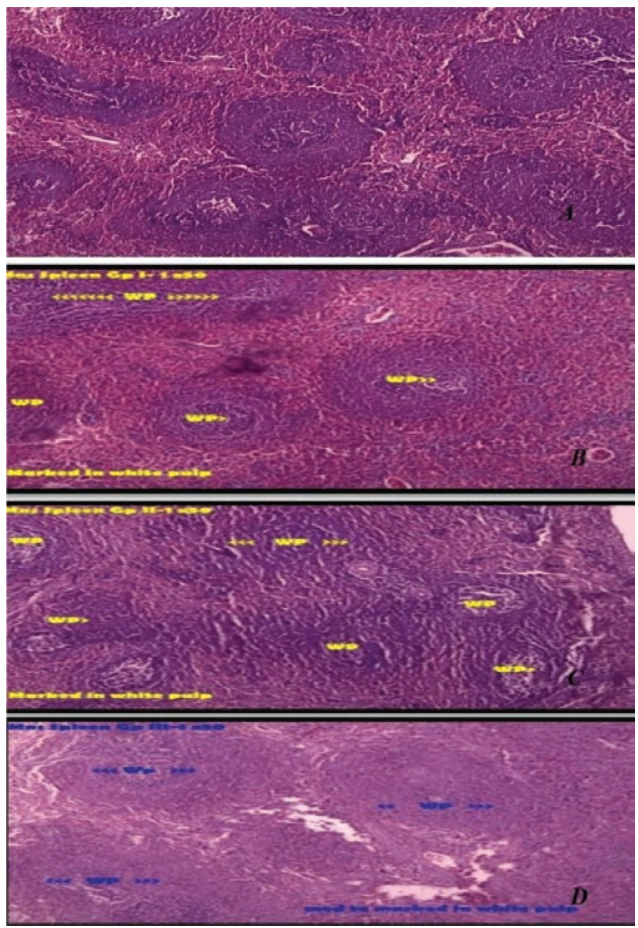

Figure 3: Photomicrograph of representative sections of Spleen. A-Normal control, B-Jayapala Seeds, C- Jayapala Seeds + Nimbu swarasa (TED), D- Jayapala Seeds + Nimbu swarasa (TEDX2). Wp- white pulp, Rp- Red pulp.

sections from Jayapala seed group showed mild cell infiltration and fatty changes in the hepatocyte in one rat, mild diffused necrosis in the second rat, mild cell depletion in the hepatocytes located in the sub-scapular region in third rat and moderate diffused necrosis was observed in the fourth rat. In two rats from Jayapala seed +Nimbu swarasa TED group, almost normal cytoarchitecture was observed while in two fatty changes of mild to moderate intensity was observed. In Jayapala seed + Nimbu swarasa $2 \times$ TED group, mild to moderate fatty changes were observed in all the four rats from which sections were taken. In one rat focal cell infiltration was also observed. Photomicrographs of representative sections can be found in Figure 4.

\section{DISCUSSION}

Repeated administration of Jayapala seed powder showed significant increase in the serum biochemical parameters like SGOT, SGPT and Alkaline phosphatase. The observed elevation indicates that at the dose level studied, Jayapala might have produced liver injury. The transaminases also get elevated when there is inflammation at different sites or more than one organ. ${ }^{15}$ Moreover, the histopathological studies with liver tissues indicates mild to moderate changes suggesting that Jayapala might have affected the liver function specifically. It 


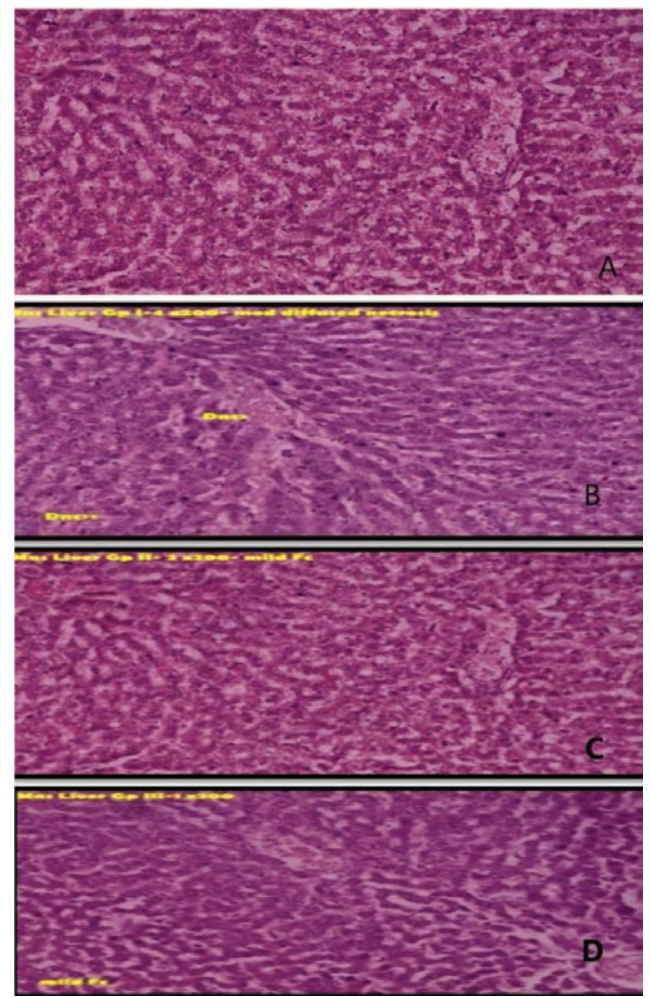

Figure 4: Photomicrograph of representative sections of Liver, A-Normal control, B-Jayapala Seeds, C- Jayapala Seeds (TED), D- Jayapala Seeds + Nimbu swarasa (TEDX2). Hc- Hepatocyte, CV- central vein, Kc- Kuffer cells, S-Sinusoidal.

is observed that among three LFT parameters, SGOT showed an increase in Jayapala administered group when compared to control group which was statistically significant. SGOT usually increases due to some damage process of liver cell. ${ }^{16}$ It is remarkable to observe that this elevation was found to be decreased in the antidote groups. Which was statistically significant. This indicates that there might be an antidote effect of Nimbu swarasa against Jayapala seed.

An increase was observed in SGPT in the Jayapala administered group when compared to the control group which was statistically significant. This might be due to liver damage or biliary duct problems. ${ }^{17}$ Increased SGPT is also one of the causes involving necrosis of hepatocytes or skeletal muscle cells ${ }^{18}$ which goes along with the raise in SGOT. As explained above this elevation was found to be significantly reversed by the antidote administration. It indicates that there might be a moderate antidote effect of Nimbu swarasa against Jayapala seed. There was an increase in the ALP in the Jayapala administered group when compared to the control group which is statistically non-significant, suggesting a progressing injury to the liver. ${ }^{19}$ But in the antidote groups of both doses, the ALP has decreased when compared to the Jayapala administered group which indicates that there might have been an antidote effect over Jayapala seed group.

Among all kidney function test parameters, a nonsignificant mild increase was observed in the blood Creatinine level in the Jayapala administered group when compared to the control group. Raised serum creatinine is usually noticed in conditions like excessive loss of body fluids (dehydration), kidney problems such as kidney damage or failure, muscle problems, such as breakdown of muscle fibers. ${ }^{20}$ It may either be due to excessive production or acute kidney injury caused by the toxicity of the non-protein hem pigment that is released from myoglobin..$^{21}$ Jayapala seeds when administered caused diarrhoea and when given continuously has lead to dehydration. This might be the reason for the observed mild elevation. Since serum urea is not affected this mild elevation is not likely to indicate kidney malfunctioning. In the antidote groups of both doses, the Creatinine level has been decreased when compared to the control group which is statistically significant. This suggests the antidote activity of Nimbuswarasa on Jayapala, reversing the toxicity produced by whatever mechanism.

Even though statistically not significant, blood urea level has been decreased in the Jayapala administered group when compared to the control group. Blood urea decrease is indicative of low nitrogen turnover. This may be due to the effect of toxicant on the liver function. Moderate but non-significant reversal of this effect was observed with higher dose anti-dote groupindicative of the effect of anti-dote on this parameter.

Among the electrolyte parameters observed, there was a significant decrease in serum sodium in Jayapala administered group when compared to the control group. Hyponatremia might be due to dehydration, diarrhoea leading to relative deficit of free water in the body / dehydration ${ }^{22,23}$ but in the antidote groups of both doses, serum sodium level increased when compared to the Jayapala administered group which was statistically non-significant. This can be considered as the reversal of the toxicant induced adverse effect by the anti-dote. The potassium level showed non-significant increase in Jayapala alone administered group. Unexpectedly in both the antidote group further elevation was observed. The elevation was statistically significant with respect to higher dose. The exact reasons are not known. Some of the causes generally causing such an effect are - acidosis, on-going tissue destruction, burns over the large area in the body, damage to muscle, severe bleeding from the stomach or intestines ${ }^{24}$ Since this parameter is not 
affected to significant extent by Jayapala the observed changes do not contribute to the determination of the anti-dote effect. It indicates the possibility that the antidote at higher dose or possibly the combination of the toxicant and anti-dote may produce one or the other changes mentioned above to cause such an elevation. Histopathological changes suggest that administration of Jayapala produced changes mainly in liver, jejunum, colon and spleen. Mild cell infiltration and fatty changes in the hepatocyte with mild to moderate diffused necrosis were observed in liver in the Jayapala administered group. In lower dose antidote group most of these degenerative changes were found to be greatly attenuated leading to observation of moderate intensity fatty changes. In higher dose antidote group moderate intensity fatty changes were observed and necrosis and cell infiltration was absent. The changes mentioned above got reflected in elevated level of transaminases. These effects were reversed in the anti-dote groups providing further evidence for their effectiveness. In colon from Jayapala alone group mild epithelial erosion was observed in the sections. The antidote groups of both doses exhibited shortening of the epithelial layer but along with necrosis. Thus in this case the effect of anti-dote seems to be limited at lower dose and moderate at higher dose level.

Examination of jejunum sections from Jayapala administered group showed mild to moderate epithelial disruption. In antidote groups of both doses, these changes were found to be less suggesting moderate antagonism of the pathological changes. Microscopic examination of sections of spleen was indicative of inflammation occurring in nearby tissues. This response was found to be attenuated in two rats in lower dose antidote group while in higher dose group moderate increase was observed. This clearly shows that the anti-dote administration at both the dose level was able to moderately reverse the effect of Jayapala induced toxicity.

\section{CONCLUSION}

Knowledge of specific antidote can be lifesaving in circumstances of toxicity owing to improper methods of purification or improper dose which may help to decrease the morbidity and mortality. The biochemical parameters and histopathological results are evident of the antidote prospectives of Nimbu swarasa on Jayapala induced toxicity. Hence, based on overall results it is very clear that Nimbu swarasa has effective antidote potentials against Jayapala induced toxicity.

\section{ACKNOWLEDGEMENT}

The authors highly acknowledge SDM Ayurveda College and SDM Research centre for the infrastructure provided for the work. The authors also thank Dr. B. Ravishankar, Ex. Director, SDM Research Centre, Udupi, for his guidance and support.

\section{Limitations of the study}

Though the study is conducted as per "The repeated dose 28-Day Oral Toxicity Study in Rodents” 407 OECD guidelines, certain variations have been made - like only 6 animals inclusive of either sex were used in each group and not 10 . These changes were done as it was a preliminary study with no prior data available for a study of such a kind. Based on the data obtained, a well planned, several test dose groups study strictly adhering to the OECD repeated dose toxicity guidelines may be planned. The euthanasia method adopted was overdose of ether which may lead to artifacts. Hence this may be avoided in future studies.

\section{CONFLICT OF INTEREST}

The authors declare no conflict of interest.

\section{ABBREVIATIONS}

OECD: Organization for Economic Co-operation and Development; SGOT: Serum glutamate oxaloacetate transaminase; SGPT: Serum glutamate pyrovet transaminase; ALP: Alkaline phosphatise; WBC: White blood cells; RBC: Red blood cells; PCV: Packed cell volume; MCV: Mean cell volume; $\mathbf{M C H}$ : Mean cell haemoglobin; MCHC: Mean cell haemoglobin concentration; RDWCV: Red cell distribution width coefficient variation; RDWSD: Red cell distribution width standard deviation; TED: Therapeutically effective dose.

\section{REFERENCES}

1. Sharma S author, Shastri K editor. Rasatarangini. 24/163-64. 11th ed. Varanasi: Motilal Banarasidas; 2012. 676.

2. Warrier V. P.S author, Warrier P.K, Nambiar V.P. K, Ramankutty C editor. Indian Medicinal plants, Kottakal: Orient Longman Private Ltd. Vol. 3. Arya Vaidya Sala; 1998. p. 223.

3. Sharma S author, Shastri K editor. Rasatarangini. 24/318-19. 11th ed. Varanasi: Motilal Banarasidas; 2012. 682.

4. Wang X, Lan M, Wu HP, Shi YQ, Lu J, Ding J, Wu KC, Jin JP, Fan DM. Direct effect of croton oil on intestinal epithelial cells and colonic smooth muscle cells. World J Gastroenterol. 2002;8(1):103-7. doi: 10.3748/wjg.v8.i1.103, PMID 11833082.

5. Tsai JC, Tsai S, Chang WC. Effect of ethanol extracts of three Chinese medicinal plants with laxative properties on ion transport of the rat intestinal epithelia. Biol Pharm Bull. 2004;27(2):162-5. doi: 10.1248/bpb.27.162, PMID 14758025. 
6. Morimura K. The role of special group article in ancient Chinese medical prescription. Hist Sci (Tokyo). 2003;13(1):1-12. PMID 14743827.

7. Rao NK. Text book of Forensic Medicine and Toxicology. 2nd ed. New Delhi: Jaypee brothers medical publishers Pvt .Ltd. Vol. 476; 1994.

8. Anonymous. The ayurvedic Pharmacopia of India. Part -1, vol. 2. New Delhi: Government of India, Ministry of health and family welfare, Department of India systems of medicine and Homeopathy; 2002. 58-9.

9. Modi J.P author, Justice Kannan editor. Modi's textbook of Medical Jurisprudence and Toxicology. 24th ed. Nagpur: Lexis Nexis, Butterworth; 2019. 137-8.

10. Biswas G Review of Forensic Medicine and Toxicology. 2nd ed. New Delhi: Jaypee brothers medical publishers Pvt .Ltd;2015:459.

11. Zhang DD, Zhou B, Yu JH, Xu CH, Ding J, Zhang H, Yue J. Cytotoxic tiglianetype diterpenoids from Croton tiglium. Tetrahedron. 2015;71(52):9638-44. doi: 10.1016/j.tet.2015.10.070.

12. Stirpe F, Pession-Brizzi A, Lorenzoni E, Strocchi P, Montanaro L, Sperti S. Studies on the proteins from the seeds of Croton tiglium and of Jatropha curcas. Toxic properties and inhibition of protein synthesis in vitro. Biochem J. 1976;156(1):1-6. doi: 10.1042/bj1560001, PMID 942394.

13. Vaidya BG, Adarsha N. Vol. 2. Varanasi: Chaukhamba Bharati Academy; 2009; $\mathrm{p}-44$.

14. Bhat SK. A Pilot Study to Evaluate The Antidotal Activity of Nimbu swarasa (Citrus medica) on Jayapala Seed (Croton tiglium) induced Toxicity on Wistar rats. JETIR. June 2018;6:851-57.

15. Aragon G, Younossi ZM. When and how to evaluate mildly elevated liver enzymes in apparently healthy patients. Cleve Clin J Med. 2010;77(3):195-204. doi: 10.3949/ccjm.77a.09064, PMID 20200170.

16. Verslype C. Evaluation of abnormal liver-enzyme results in asymptomatic patients. Acta Clin Belg. 2004;59(5):285-89. doi: 10.1179/acb.2004.042, PMID 15641399.
17. Giannini EG, Testa R, Savarino V. Liver enzyme alteration: a guide for clinicians. CMAJ. 2005;172(3):367-79. doi: 10.1503/cmaj.1040752, PMID 15684121.

18. Miyake S. The mechanism of release of hepatic enzymes in various liver diseases. II. Altered activity ratios of GOT to GPT in serum and liver of patients with liver diseases. Acta Med Okayama. 1979;33(5):343-58. PMID 160182.

19. Giannini E, Botta F, Fasoli A, Ceppa P, Risso D, Lantieri PB, Celle G, Testa R. Progressive liver functional impairment is associated with an increase in AST/ ALT ratio. Dig Dis Sci. 1999;44(6):1249-53. doi: 10.1023/a:1026609231094, PMID 10389705.

20. Grover DS, Atta MG, Eustace JA, Kickler TS, Fine DM. Lack of clinical utility of urine myoglobin detection by microconcentrator ultra filtration in the diagnosis of rhabdomyolysis. Nephrol Dial Transplant. 2004;19(10):2634-8. doi: 10.1093/ndt/gfh422, PMID 15280520.

21. Stevens LA, Lafayette RA, Perrone RD. Levey AS author, Scrier RW, editor. Laboratory evaluation of kidney function. Diseases of the kidney and urinary tract. 8th ed. Philadelphia: Lippincott Williams \& Wilkins; 2007.

22. Pincus MR: Chap 8. Abraham NZ Jr authors. In: McPherson RA, Pincus MR, editors Interpreting laboratory results Henry's clinical diagnosis and management by laboratory methods. 22nd ed. Philadelphia: Elsevier Saunders; 2011.

23. Shorecki K, Ausiello D: Chap 118. Disorders of sodium and water homeostasis. In: Goldman L, Schafer Al, editors Goldman's Cecil medicine. 24th ed. Philadelphia: Elsevier Saunders; 2011.

24. Acker CG, Johnson JP, Palevsky PM, Greenberg A. Hyperkalemia in hospitalized patients: causes, adequacy of treatment, and results of an attempt to improve physician compliance with published therapy guidelines. Arch Intern Med. 1998;158(8):917-24. doi: 10.1001/archinte.158.8.917, PMID 9570179.

\section{SUMMARY}

- Repeated administration of Jayapala seed powder caused significant elevation in the serum liver enzymes like SGOT and SGPT and marked rise in the serum creatinine level. The co-administration of antidote Nimbu swarasa significantly attenuated Jayapala seed induced increase in the liver enzymes and reduced serum creatinine level.

- Histopathological examination of colon and jejunum revealed moderate epithelial cell erosions by Jayapala seed powder administration, whereas Nimbu swarasa caused mild to moderate protection in a dose dependant manner.

- Sections of spleen showed remarkable increase in the proportion of white pulp in Jayapala seeds administered group, whereas the Nimbu swarasa at higher dose level showed marked decrease in the white pulp proportion.

- Mild cell infiltration and fatty changes in the hepatocyte with mild diffused necrosis was noticed by repeated administration of Jayapala seed powder whereas the sections of co-administration of antidotes showed normal cytoarchitecture.

- Nimbu swarasa may be an effective antidote against Jayapala seed powder induced toxicity. 


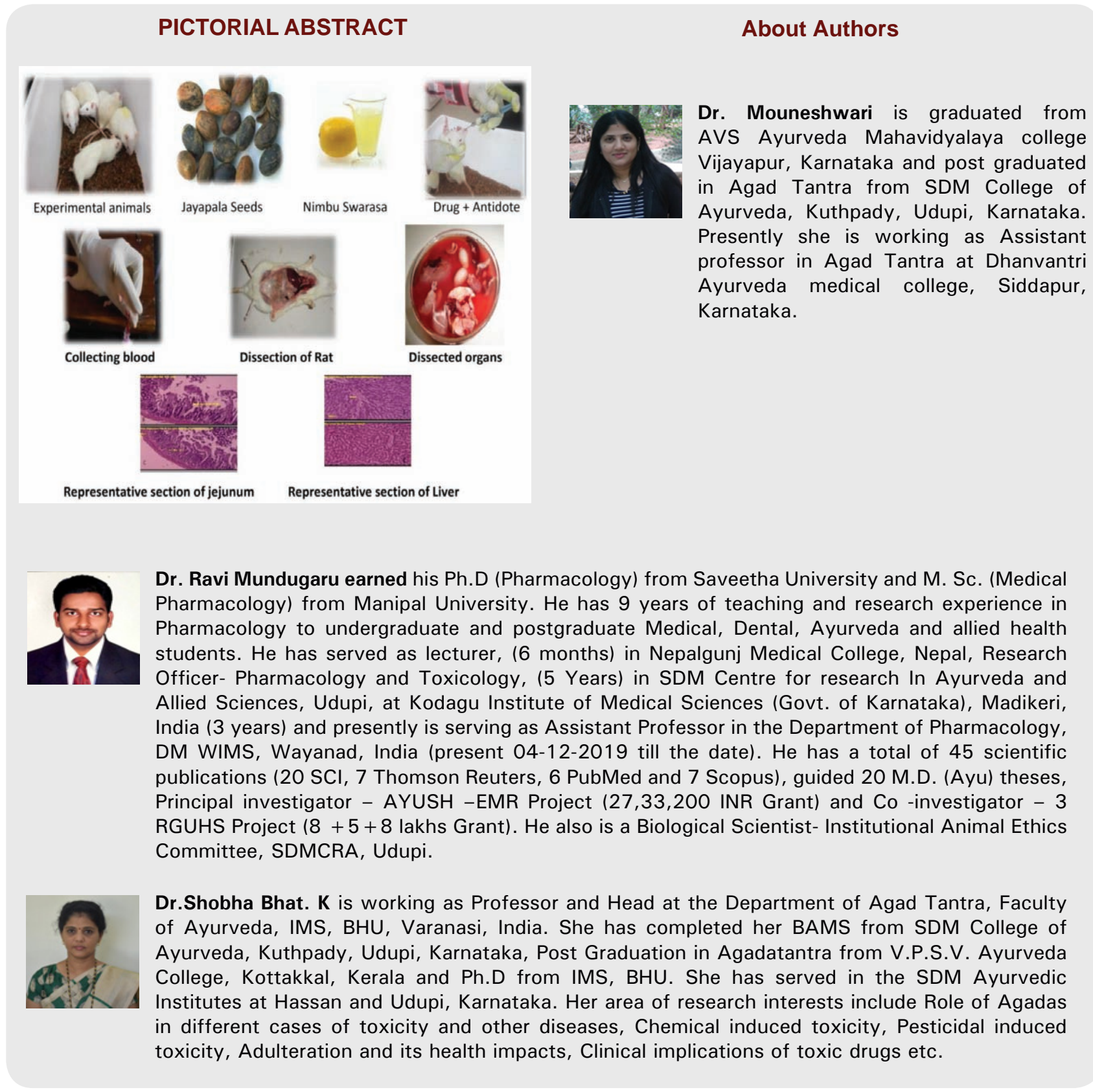

Cite this article: Mouneshwari, Ravi M, Bhat SK. Evaluation of the Antidote Activity of Nimbu swarasa (Citrus limon Linn.) on Jayapala Seed (Croton tiglium Linn.) Induced Toxicity in Wistar Albino Rats. Indian J of Pharmaceutical Education and Research. 2021;55(3s):s774-s783. 